\title{
EFFECTS OF SINGLE, BINARY AND TERTIARY COMBINATIONS WITH Jatropha gossypifolia AND OTHER PLANT-DERIVED MOLLUSCICIDES ON REPRODUCTION AND SURVIVAL OF THE SNAIL Lymnaea acuminata
}

\author{
Ram P. YADAV \& Ajay SINGH
}

\begin{abstract}
SUMMARY
The effect of sub-lethal doses $\left(40 \%\right.$ and $80 \%$ of $\left.\mathrm{LC}_{50} / 24 \mathrm{~h}\right)$ of plant derived molluscicides of singly, binary (1:1) and tertiary (1:1:1) combinations of the Rutin, Ellagic acid, Betulin and taraxerol with J. gossypifolia latex, leaf and stem bark powder extracts and their active component on the reproduction of freshwater snail Lymnaea acuminata have been studied. It was observed that the J. gossypifolia latex, stem bark, individual leaf and their combinations with other plant derived active molluscicidal components caused a significant reduction in fecundity, hatchability and survival of young snails. It is believed that sub-lethal exposure of these molluscicides on snail reproduction is a complex process involving more than one factor in reducing the reproductive capacity.
\end{abstract}

KEYWORDS: Lymnaea; Fascioliasis; Jatropha gossypifolia; Molluscicides

\section{INTRODUCTION}

The freshwater snail Lymnaea acuminata is the intermediate host of the liver flukes Fasciola hepatica and Fasciola gigantica, which cause endemic fascioliasis in cattle and livestock, in eastern Uttar Pradesh, India ${ }^{1,13,26,28,38,39}$. This snail breeds all year-round and lays eggs on the lower surface of the aquatic plants, which are used by poor people as fodder for cattle and livestock.

One way to tackle the problem of fascioliasis is to delink the life cycle of the flukes by destroying the carrier snails ${ }^{1,9,14,25,26}$. Molluscan pests can be destroyed by the use of molluscicide ${ }^{18,33,37}$. This can be achieved with the aid of synthetic products or, alternatively, with molluscicide from plant sources ${ }^{17,25,26,27}$. Molluscicides of plant origin have gained more importance, because they are ecologically sound and culturally more acceptable than synthetic ones.

The aim of the present study is to evaluate the effects of the above noted plant-derived molluscicides on the reproduction (fecundity, egg viability and survival of young snails) of Lymnaea acuminata in single, binary and tertiary combinations with different active compounds, such as rutin of Croton tiglium, ellagic acid of Euphorbia hirta, taraxerol of Codiaeum variegatum and betulin of Euphorbia lathyrus and Jatropha gossypifolia latex, stem bark and leaf powder.

\section{MATERIALS AND METHODS}

Leaf, stem bark and latex of Jatropha gossypifolia were collected locally from their natural habitat and identified by the Botany Department, University of Gorakhpur (U.P) India. The leaf and stem bark of Jatropha gossypifolia were kept in an incubator at $37{ }^{\circ} \mathrm{C}$ for 48 hours. Dried pieces of leaf and stem bark were pulverized in a grinder. The latex of the Jatropha gossypifolia was drained into glass tubes by cutting their stem apices; this latex was lyophilized at $-40{ }^{\circ} \mathrm{C}$ and lyophilized powder was stored for further use. The freeze-dried powder was mixed with an appropriate volume of distilled water to obtain the desired concentrations. The sub-lethal doses $\left(40 \%\right.$ and $\left.80 \% \mathrm{LC}_{50} / 24 \mathrm{~h}\right)$ using Jatropha gossypifolia latex, stem bark and leaf, in a single, binary and tertiary combination with rutin, ellagic acid, taraxerol and betulin for the reproduction studied ${ }^{41}$.

Rutin $\left(\mathrm{C}_{27} \mathrm{H}_{30} \mathrm{O}_{16}\right)\left(\right.$ EC NO-205-814-1), Ellagic acid $\left(\mathrm{C}_{14} \mathrm{O}_{6} \mathrm{O}_{8}\right)$ (4,4,5,5,6,6-Hexahydroxydiphenic acid, 2,6,2,6-dilactone) (EC NO207-508-3), Betulin $\left(\mathrm{C}_{30} \mathrm{H}_{50} \mathrm{O}_{2}\right)$ (Lup-20(2a)-ene-3 $\beta$-28-diol) (EC NO-207-475-6) supplied by Sigma Chemical Co. P.O. Box 14508 St. Louis. Mo.63178 USA 314-771-5750. Rutin is obtained from the leaf of Croton tiglium $^{23}$, Ellagic acid is found in the flower of Euphorbia hirta ${ }^{11}$ and Betulin is found in the stem bark of Euphorbia lathyrus ${ }^{24}$, taraxerol extracted from the stem-bark of Codiaeum variegatum ${ }^{40}$ and latex of Jatropha gossypifolia were prepared using the method of YADAV \& SINGH $^{41}$. Different binary $(1: 1)$ and tertiary $(1: 1: 1)$ combinations were prepared with lyophilized powder of Jatropha gossypifolia with Rutin, Ellagic acid, Taraxerol and Betulin.

Fecundity Experiments: The snail was transferred from the earthen cemented ponds to laboratory conditions for fecundity, survival and

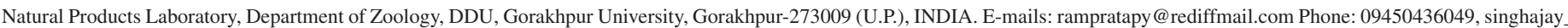
gkp@rediffmail.com Phone no. 0551-2201171 (o) 2202127 (R).
} 


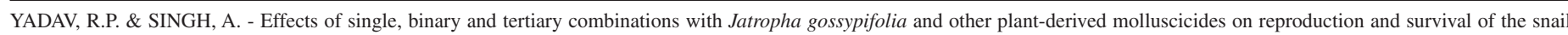
Lymnaea acuminata. Rev. Inst. Med. Trop. Sao Paulo, 56(5): 421-6, 2014.

hatchability experiments in three sets of aquaria, each of them set up and filled with $5 \mathrm{~L}$ natural pond water which were prepared with extracts of latex, stem bark and leaf of J. gossypifolia, rutin, ellagic acid, betulin and taraxerol extracts of active compounds. The first set was treated with $40 \%$ of $\mathrm{LC}_{50}(24 \mathrm{~h})$, the second set with $80 \%$ of $\mathrm{LC}_{50}(24 \mathrm{~h})$ of latex, stem bark and leaf powder of Jatropha gossypifolia singly and combination of active compound, while the third set of the aquarium contained only natural pond water without any treatment (i.e. control). Fifty snails were placed in each aquarium for the fecundity tests. Each set of aquarium contained six replicates, water temperatures were kept at $23 \pm 1.5^{\circ} \mathrm{C}$ during the whole experiment.

The freshwater adult snail Lymnaea acuminata $(2.6 \pm 0.3 \mathrm{~cm}$ in shell length) were collected from freshwater ponds and stored for 48 hours in glass aquaria containing dechlorinated tap water. These snails lay their eggs in the form of an elongated gelatinous capsule containing 5 -180 eggs. Groups of 20 snails in 5L water were exposed to sub-lethal concentrations ( $40 \%$ and $80 \%$ of LC $_{50} / 24 \mathrm{~h}$ ) of single, binary (1: 1$)$ and tertiary combinations $(1: 1: 1)$ for survival and hatchability of snails.

As it is difficult to detect the mother snails for a particular spawn, capsules containing eggs from each treated group were incubated at $30{ }^{\circ} \mathrm{C}$, in covered petri dishes, containing the same concentration as given to adult snails. The development of embryos was observed under a binocular microscope at regular intervals up until their hatching. Percentage hatching was studied with the eggs laid after a 24 hours exposure period. Dead eggs were removed to avoid any water contamination. Survival of young snails was observed up to 72 hours after hatching.

Statistical Analysis: Student's 't' test was applied to determine the significant $(p<0.05)$ differences between treated and controlled animals. Analysis of variance was applied to determine the significant differences observed in the fecundity caused by the different combinations. A product moment correlation coefficient was applied in between exposure time and fecundity/survival of snails ${ }^{29}$.

\section{RESULTS}

Lymnaeid snails attached spawns (egg masses), containing a large number of eggs to the back surface of Nymphaea leaf when reproducing. The spawns produced every 24 hours and the number of eggs was counted under a compound microscope. As each group spawned, they were transferred into separate Petri dishes for hatching under the same exposure conditions as above. Numbers of hatched snails were counted and their survivability was recorded up to 72 hours after the hatching.

The cumulative number of eggs decreased during the treatment of $J$. gossypifolia latex, stem bark and leaf, a binary combination (1:1) of $J$. gossypifolia latex+rutin, J. gossypifolia latex+ellagic acid, J. gossypifolia latex+taraxerol and tertiary combinations (1:1:1) J. gossypifolia latex+rutin+betulin, J. gossypifolia latex+ellagic acid+betulin and J. gossypifolia latex+taraxerol+betulin extracts than those that were controlled. Snails exposed to the above extract showed reduced oviposition at all the sub-lethal doses $\left(40 \%\right.$ and $80 \%$ of $\left.\mathrm{LC}_{50} / 24 \mathrm{~h}\right)$ of exposure periods. Decrease in the number of eggs is significantly lower when exposed to all the sub-lethal doses of the extract. All the laid eggs, which were placed in the glass Petri dishes for hatching and survivability test, are shown in (Tables 1, 2 and 3).

Tables 1, 2 and 3 show that the treatment with the sub-lethal doses ( $40 \%$ and $80 \%$ of $\mathrm{LC}_{50} / 24 \mathrm{~h}$ ) of $J$. gossypifolia latex, stem bark and leaf of the binary combinations (1:1) J. gossypifolia latex+rutin, $J$. gossypifolia latex+ellagic acid, J. gossypifolia latex+taraxerol and tertiary (1:1:1) J. gossypifolia latex+rutin+betulin, J. gossypifolia latex+ellagic acid+betulin and $J$. gossypifolia latex+taraxerol+betulin caused a significant reduction in the hatchability of freshwater snails L. acuminata.

After $72 \mathrm{~h}$ of hatching, $100 \%$ mortality was observed in the young snails of $L$. acuminata exposed to concentrations of $24 \mathrm{~h}$ leaf, $48 \mathrm{~h}$ latex, stem bark and leaf, 72h latex, stem bark and leaf, 96h latex, stem bark and leaf (Table 1). The same trend was also observed in binary (1:1) combination (Table 2) and tertiary (1:1:1) combination (Table 3). The hatching period was also observed in treated groups (9-16 days) in respect to controlled groups (11-17 days) (Tables 1, 2 and 3).

\section{DISCUSSION}

It is evident from the results that the sub-lethal exposure $(40 \%$ and $80 \%$ of $\mathrm{LC}_{50} / 24 \mathrm{~h}$ ) with $J$. gossypifolia latex, leaf and stem bark and their different combinations with betulin, ellagic acid, rutin and taraxerol caused a significant reduction in survival and hatchability of snail L. acuminata. Increased egg laying was also observed in the freshwater snail Lymnaea stagnalis under fenvalerate exposure ${ }^{22}$. NOMURA et al., (1979) ${ }^{21}$ identified prostaglandins in mollusks by using a thin layer chromatography to indicate that prostaglandins may be playing a critical role in the gametogenesis of snails as well. Induction of spawning behavior by prostaglandins was observed in fish ${ }^{10}$. Prostaglandins have been shown to control estrous, ovulation and fertility ${ }^{20}$. The prostaglandin level in snails might be increased after extract exposure. Prostaglandins, rather than acting as hormones, may modulate the action of other hormones responsible for spawning behavior ${ }^{30}$. HAFS et al., (1974) $)^{12}$ reported that $\mathrm{PGE}_{1}$ and $\mathrm{PGF}_{2} \alpha$ also affect the release of luteinizing hormone and follicle stimulating hormone indicating the critical role that prostaglandins play in the control of gonadotropin release. It may be possible that the extract induced the prostaglandin level in freshwater snail Lymnaea acuminata results deposition of many more eggs compared to those controlled.

VAN DEN BIGGELAAR (1971a, 1971b, 1971c) ) $^{34,35,36}$ pointed out a relationship between the length of the cell cycle and amount of RNA synthesis in Lymnaea, and ${ }^{16}$ has expanded this topic to rRNA synthesis. KIDDER $(1976 b)^{16}$ suggested that a rapid cell cycle does not permit enough time for the formation of functional nucleoli, which are probably required for rRNA synthesis. Observations show that there is no enhancement of rRNA transcription of gastrulation in this species and that the measured level of transcription would not be detectable during early cleavage when each embryo consists of only a few cells. Furthermore, the time for the initiation of rRNA synthesis for Lymnaea, Acmaea, Oncopeltus and the rabbit ${ }^{15}$ do not support a correlation between the length of the cell cycle and the onset of rRNA synthesis.

The activation of rDNA transcription would be misleading, in regard to the regulation of transcription. The answer to this question may be a low level of rRNA synthesis modulated at various stages of embryogenesis. Ribosomal RNA synthesis has been shown to continue 


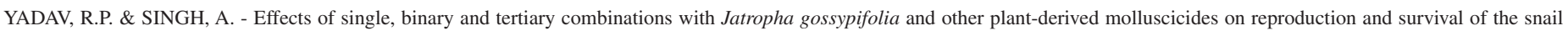
Lymnaea acuminata. Rev. Inst. Med. Trop. Sao Paulo, 56(5): 421-6, 2014.

Table 1

Effects of sub-lethal exposure $\left(40 \%\right.$ and $80 \%$ of $\left.24 \mathrm{~h} \mathrm{LC}_{50}\right)$ of the extracts of latex, stem bark and leaf on hatchability and survival of young snail Lymnaea acuminata at different time intervals

\begin{tabular}{|c|c|c|c|c|c|c|}
\hline & Plant part tested & $\begin{array}{c}\text { Concentrations } \\
(\mathrm{mg} / \mathrm{L})\end{array}$ & $\begin{array}{c}\% \text { Hatchability } \\
\text { (hatching period in days) }\end{array}$ & $\begin{array}{c}\text { Survival 24h after } \\
\text { hatching }(\%)\end{array}$ & $\begin{array}{c}\text { Survival } 48 \mathrm{~h} \text { after } \\
\text { hatching }(\%)\end{array}$ & $\begin{array}{c}\text { Survival } 72 \mathrm{~h} \text { after } \\
\text { hatching }(\%)\end{array}$ \\
\hline \multirow{7}{*}{$24 \mathrm{~h}$} & \multirow{3}{*}{ Latex } & Control & $100(11-17)$ & 100 & 100 & 100 \\
\hline & & $40 \%$ of $24 \mathrm{~h} \mathrm{LC}_{50}(4.12)$ & $362.33 \pm 1.086(11-16)$ & $312.33 \pm 1.763$ & $272.50 \pm 0.375$ & $86.50 \pm 0.736$ \\
\hline & & $80 \%$ of $24 \mathrm{~h} \mathrm{LC}_{50}(8.24)$ & $332.66 \pm 0.926(12-17)$ & $265.48 \pm 0.136$ & $208.50 \pm 1.012$ & $71.83 \pm 0.524$ \\
\hline & \multirow{2}{*}{ Stem bark } & $40 \%$ of $24 \mathrm{~h} \mathrm{LC}_{50}(5.06)$ & $286.66 \pm 1.808(11-16)$ & $232.19 \pm 0.215$ & $197.79 \pm 0.285$ & - \\
\hline & & $80 \%$ of $24 \mathrm{~h} \mathrm{LC}_{50}(10.12)$ & $271.33 \pm 0.968(12-17)$ & $225.66 \pm 0.366$ & $192.64 \pm 0.223$ & - \\
\hline & \multirow{2}{*}{ Leaf } & $40 \%$ of $24 \mathrm{~h} \mathrm{LC}_{50}(9.84)$ & $284.16 \pm 1.183(11-16)$ & $258.58 \pm 0.075$ & $196.07 \pm 0.014$ & - \\
\hline & & $80 \%$ of $24 \mathrm{~h} \mathrm{LC}_{50}(19.68)$ & $265.76 \pm 0.354(12-17)$ & $212.60 \pm 0.093$ & $172.44 \pm 0.057$ & - \\
\hline \multirow{6}{*}{$48 \mathrm{~h}$} & \multirow{2}{*}{ Latex } & $40 \%$ of $24 \mathrm{~h} \mathrm{LC}_{50}(3.44)$ & $265.33 \pm 0.926(11-16)$ & $212.48 \pm 5.248$ & $185.73 \pm 0.019$ & - \\
\hline & & $80 \%$ of $24 \mathrm{~h} \mathrm{LC}_{50}(6.88)$ & $254.16 \pm 0.956(12-17)$ & $211.12 \pm 0.330$ & $181.70 \pm 0.012$ & - \\
\hline & \multirow{2}{*}{ Stem bark } & $40 \%$ of $24 \mathrm{~h} \mathrm{LC}_{50}(4.15)$ & $118.33 \pm 0.881(11-16)$ & $78.09 \pm 0.312$ & $60.34 \pm 0.063$ & - \\
\hline & & $80 \%$ of $24 \mathrm{~h} \mathrm{LC}_{50}(8.30)$ & $113.33 \pm 0.785(12-17)$ & $89.26 \pm 0.127$ & $57.00 \pm 0.750$ & - \\
\hline & \multirow{2}{*}{ Leaf } & $40 \%$ of $24 \mathrm{~h} \mathrm{LC}_{50}(5.34)$ & $125.16 \pm 1.564(11-16)$ & $101.37 \pm 3.307$ & $82.60 \pm 0.106$ & - \\
\hline & & $80 \%$ of $24 \mathrm{~h} \mathrm{LC}_{50}(10.68)$ & $120.33 \pm 0.543(12-17)$ & $84.23 \pm 0.177$ & $73.40 \pm 0.105$ & - \\
\hline \multirow{6}{*}{$72 \mathrm{~h}$} & \multirow{2}{*}{ Latex } & $40 \%$ of $24 \mathrm{~h} \mathrm{LC}_{50}(2.66)$ & $131.50 \pm 2.874(11-16)$ & $84.16 \pm 5.960$ & $76.27 \pm 0.105$ & - \\
\hline & & $80 \%$ of $24 \mathrm{~h} \mathrm{LC}_{50}(5.32)$ & $122.10 \pm 0.108(12-17)$ & $82.22 \pm 0.401$ & $71.00 \pm 0.223$ & - \\
\hline & \multirow{2}{*}{ Stem bark } & $40 \%$ of $24 \mathrm{~h} \mathrm{LC}_{50}(3.51)$ & $366.83 \pm 0.870(11-16)$ & $227.43 \pm 0.613$ & $150.40 \pm 0.018$ & - \\
\hline & & $80 \%$ of $24 \mathrm{~h} \mathrm{LC}_{50}(7.02)$ & $365.16 \pm 1.485(12-17)$ & $220.83 \pm 0.870$ & $143.50 \pm 0.885$ & - \\
\hline & \multirow{2}{*}{ Leaf } & $40 \%$ of $24 \mathrm{~h} \mathrm{LC}_{50}(4.66)$ & $343.00 \pm 0.802(11-16)$ & $277.83 \pm 0.010$ & $168.07 \pm 0.112$ & - \\
\hline & & $80 \%$ of $24 \mathrm{~h} \mathrm{LC}_{50}(9.32)$ & $333.50 \pm 1.089(12-17)$ & $266.00 \pm 0.567$ & $156.33 \pm 0.543$ & - \\
\hline \multirow{6}{*}{$96 \mathrm{~h}$} & \multirow{2}{*}{ Latex } & $40 \%$ of $24 \mathrm{~h} \mathrm{LC}_{50}(2.26)$ & $328.00 \pm 1.022(11-16)$ & $291.92 \pm 0.010$ & $157.44 \pm 0.164$ & - \\
\hline & & $80 \%$ of $24 \mathrm{~h} \mathrm{LC}_{50}(4.52)$ & $323.00 \pm 1.289(12-17)$ & $277.78 \pm 0.017$ & $143.16 \pm 0.660$ & - \\
\hline & \multirow{2}{*}{ Stem bark } & $40 \%$ of $24 \mathrm{~h} \mathrm{LC}_{50}(3.25)$ & $315.00 \pm 1.500(11-16)$ & $192.15 \pm 0.055$ & $163.80 \pm 0.072$ & - \\
\hline & & $80 \%$ of $24 \mathrm{~h} \mathrm{LC}_{50}(6.50)$ & $287.83 \pm 1.868(12-17)$ & $204.35 \pm 0.568$ & $153.83 \pm 0.870$ & - \\
\hline & \multirow{2}{*}{ Leaf } & $40 \%$ of $24 \mathrm{~h} \mathrm{LC}_{50}(4.22)$ & $312.50 \pm 2.117(11-16)$ & $225.00 \pm 0.968$ & $184.37 \pm 0.020$ & - \\
\hline & & $80 \%$ of $24 \mathrm{~h} \mathrm{LC}_{50}(8.44)$ & $293.66 \pm 1.491(12-17)$ & $212.33 \pm 0.463$ & $149.76 \pm 0.085$ & - \\
\hline
\end{tabular}

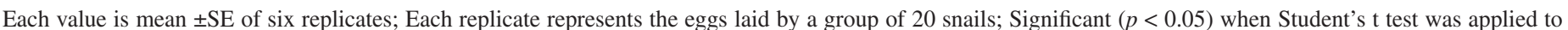
treated and control groups. -; No fecundity, hatchability or survival was observed.

until the trochophore stage in Spisula ${ }^{8}$ and Mulinia $^{15}$, and until the veliger stage in llyanassa ${ }^{7}$. The first major increase in RNA accumulation that is attributable to the synthesis of rRNA occurs only after three days of development ${ }^{6}$. Work on the incorporation of P32 into alkali stable materials of the Lymnaea eggs suggests that RNA synthesis begins in the uncleaved egg and continues during cleavage ${ }^{5,31,32}$.

The amount of protein synthesis is very low in the unfertilized egg, which increases three to fourfold after fertilization. An increase in permeability to amino acids occurred about $50 \mathrm{~min}$ after fertilization and the relative rate of protein synthesis continued to increase with a concomitant increase in polyribosomes throughout early development ${ }^{4}$. Many freshwater gastropods, typified by Lymnaea and other pond snails, undergo direct development, that is, they do not have a free living larval stage but develop in an egg capsule containing a peri-vitellin albuminous fluid. In review of protein synthesis in pulmonates, it was ${ }^{19}$ pointed out that the capsule fluid of Lymnaea is pinocytotically ingested by the embryo and presumably serves as a nutrient after the consumption of the egg yolk by the end of the gastrula. Using those points and a parallel increase of embryonic proteins with a decrease in capsular food protein that begins during the second day of development, it can be observed that reduced hatchability of $L$. acuminata exposed to different plant-derived molluscicides and their binary combinations is due to interference with embryonic growth and development of the snails. In the treated group, egg masses swelled and turned somewhat viscous. The color of the egg capsules in the control group was dark cream, but changed into white 


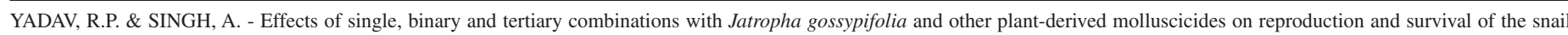
Lymnaea acuminata. Rev. Inst. Med. Trop. Sao Paulo, 56(5): 421-6, 2014.

Table 2

Effects of sub-lethal exposure $\left(40 \%\right.$ and $80 \%$ of $24 \mathrm{~h} \mathrm{LC}_{50}$ ) of the extracts of J. gossypifolia latex+rutin, J. gossypifolia latex+ellagic acids and J. gossypifolia latex+taraxerol in binary combinations (1:1) hatchability and survival of young snail Lymnaea acuminata at different time intervals

\begin{tabular}{|c|c|c|c|c|c|c|}
\hline & Plant part tested & $\begin{array}{c}\text { Concentrations } \\
(\mathrm{mg} / \mathrm{L})\end{array}$ & $\begin{array}{c}\% \text { Hatchability } \\
\text { (hatching period in days) }\end{array}$ & $\begin{array}{c}\text { Survival } 24 \mathrm{~h} \text { after } \\
\text { hatching }(\%)\end{array}$ & $\begin{array}{c}\text { Survival } 48 \mathrm{~h} \text { after } \\
\text { hatching }(\%)\end{array}$ & $\begin{array}{c}\text { Survival 72h after } \\
\text { hatching }(\%)\end{array}$ \\
\hline \multirow{7}{*}{$24 \mathrm{~h}$} & \multirow{3}{*}{$\begin{array}{l}\text { J. gossypifolia } \\
\text { latex+Rutin }\end{array}$} & Control & $100(11-17)$ & 100 & 100 & 100 \\
\hline & & $40 \%$ of $24 \mathrm{~h} \mathrm{LC}_{50}(0.54)$ & $135.83 \pm 2.666(11-16)$ & $80.13 \pm 0.082$ & $67.91 \pm 10.124$ & $35.83 \pm 0.528$ \\
\hline & & $80 \%$ of $24 \mathrm{~h} \mathrm{LC}_{50}(1.08)$ & $116.83 \pm 1.511(12-17)$ & $80.61 \pm 0.080$ & $65.42 \pm 0.094$ & $32.84 \pm 0.870$ \\
\hline & \multirow{2}{*}{$\begin{array}{c}J . \text { gossypifolia } \\
\text { latex+Ellagic acids }\end{array}$} & $40 \%$ of $24 \mathrm{~h} \mathrm{LC}_{50}(2.02)$ & $147.50 \pm 3.352(11-16)$ & $103.25 \pm 0.059$ & $84.07 \pm 0.011$ & - \\
\hline & & $80 \%$ of $24 \mathrm{hLC}_{50}(4.04)$ & $111.16 \pm 1.825(12-17)$ & $87.16 \pm 0.013$ & $54.46 \pm 0.110$ & - \\
\hline & \multirow{2}{*}{$\begin{array}{l}\text { J. gossypifolia } \\
\text { latex+taraxerol }\end{array}$} & $40 \%$ of $24 \mathrm{~h} \mathrm{LC}_{50}(4.00)$ & $107.00 \pm 1.360(11-16)$ & $96.30 \pm 0.061$ & $73.83 \pm 0.076$ & - \\
\hline & & $80 \%$ of $24 \mathrm{hLC}_{50}(8.00)$ & $95.83 \pm 0.958(12-17)$ & $79.53 \pm 0.071$ & $48.87 \pm 0.059$ & - \\
\hline \multirow{6}{*}{$48 \mathrm{~h}$} & \multirow{2}{*}{$\begin{array}{l}\text { J. gossypifolia } \\
\text { latex+Rutin }\end{array}$} & $40 \%$ of $24 h \mathrm{LC}_{50}(0.42)$ & $276.33 \pm 2.096(11-16)$ & $149.21 \pm 0.060$ & $107.76 \pm 0.108$ & - \\
\hline & & $80 \%$ of $24 \mathrm{~h} \mathrm{LC}_{50}(0.84)$ & $136.83 \pm 1.217(12-17)$ & $88.93 \pm 0.107$ & $77.99 \pm 0.094$ & - \\
\hline & \multirow{2}{*}{$\begin{array}{c}J . \text { gossypifolia } \\
\text { latex+Ellagic acids }\end{array}$} & $40 \%$ of $24 \mathrm{~h} \mathrm{LC}_{50}(1.70)$ & $290.83 \pm 2.362(11-16)$ & $189.03 \pm 0.245$ & $113.42 \pm 0.210$ & - \\
\hline & & $80 \%$ of $24 \mathrm{hLC}_{50}(3.40)$ & $275.33 \pm 2.096(12-17)$ & $176.16 \pm 0.660$ & $112.88 \pm 0.017$ & - \\
\hline & \multirow{2}{*}{$\begin{array}{l}\text { J. gossypifolia } \\
\text { latex+taraxerol }\end{array}$} & $40 \%$ of $24 \mathrm{~h} \mathrm{LC}_{50}(3.66)$ & $262.66 \pm 0.732(11-16)$ & $196.99 \pm 0.660$ & $128.70 \pm 0.034$ & - \\
\hline & & $80 \%$ of $24 \mathrm{~h} \mathrm{LC}_{50}(7.32)$ & $217.66 \pm 2.190(12-17)$ & $187.18 \pm 0.127$ & $128.41 \pm 0.095$ & - \\
\hline \multirow{6}{*}{$72 \mathrm{~h}$} & \multirow{2}{*}{$\begin{array}{l}\text { J. gossypifolia } \\
\text { latex+Rutin }\end{array}$} & $40 \%$ of $24 \mathrm{~h} \mathrm{LC}_{50}(0.34)$ & $144.83 \pm 0.440(11-16)$ & $141.33 \pm 0.675$ & $113.16 \pm 0.660$ & - \\
\hline & & $80 \%$ of $24 \mathrm{hLC}_{50}(0.68)$ & $134.00 \pm 0.401(12-17)$ & $129.33 \pm 0.231$ & $87.33 \pm 0.834$ & - \\
\hline & \multirow{2}{*}{$\begin{array}{l}\text { J. gossypifolia } \\
\text { latex+Ellagic acids }\end{array}$} & $40 \%$ of $24 \mathrm{~h} \mathrm{LC}_{50}(1.42)$ & $283.00 \pm 0.750(11-16)$ & $276.35 \pm 0.675$ & $123.32 \pm 0.968$ & - \\
\hline & & $80 \%$ of $24 \mathrm{~h} \mathrm{LC}_{50}(2.84)$ & $273.33 \pm 0.968(12-17)$ & $262.33 \pm 0.366$ & $113.50 \pm 0.838$ & - \\
\hline & \multirow{2}{*}{$\begin{array}{l}\text { J. gossypifolia } \\
\text { latex+taraxerol }\end{array}$} & $40 \%$ of $24 \mathrm{~h} \mathrm{LC}_{50}(3.16)$ & $252.50 \pm 0.838(11-16)$ & $247.16 \pm 0.772$ & $209.50 \pm 0.839$ & - \\
\hline & & $80 \%$ of $24 \mathrm{~h} \mathrm{LC}_{50}(6.32)$ & $247.50 \pm 0.680(12-17)$ & $234.33 \pm 0.675$ & $208.16 \pm 1.038$ & - \\
\hline \multirow{6}{*}{$96 \mathrm{~h}$} & \multirow{2}{*}{$\begin{array}{l}\text { J. gossypifolia } \\
\text { latex+Rutin }\end{array}$} & $40 \%$ of $24 \mathrm{~h} \mathrm{LC}_{50}(0.29)$ & $137.00 \pm 0.694(11-16)$ & $129.33 \pm 1.086$ & $95.67 \pm 0.732$ & - \\
\hline & & $80 \%$ of $24 \mathrm{hLC}_{50}(0.58)$ & $134.00 \pm 0.401(12-17)$ & $128.50 \pm 0.470$ & $82.83 \pm 0.772$ & - \\
\hline & \multirow{2}{*}{$\begin{array}{l}\text { J. gossypifolia } \\
\text { latex+Ellagic acids }\end{array}$} & $40 \%$ of $24 \mathrm{~h} \mathrm{LC}_{50}(1.13)$ & $215.33 \pm 0.675(11-16)$ & $213.00 \pm 1.022$ & $206.84 \pm 1.678$ & - \\
\hline & & $80 \%$ of $24 \mathrm{hLC}_{50}(2.26)$ & $211.16 \pm 0.660(12-17)$ & $188.50 \pm 0.470$ & $186.33 \pm 1.408$ & - \\
\hline & \multirow{2}{*}{$\begin{array}{l}J . \text { gossypifolia } \\
\text { latex+taraxerol }\end{array}$} & $40 \%$ of $24 \mathrm{~h} \mathrm{LC}_{50}(2.79)$ & $244.66 \pm 0.926(11-16)$ & $236.84 \pm 1.312$ & $207.17 \pm 1.589$ & - \\
\hline & & $80 \%$ of $24 \mathrm{~h} \mathrm{LC}_{50}(5.58)$ & $236.67 \pm 0.612(12-17)$ & $210.83 \pm 0.870$ & $182.51 \pm 0.49$ & - \\
\hline
\end{tabular}

Details as given in Table 1.

in the treated samples ${ }^{3}$. Time dependent reduction in the survival of newly hatched snails, even after transfer to fresh water, indicates that chemicals received either from the mother snail or the eggs are lethal to young newly hatched snails. It seems that the thin and fragile shell of newly hatched snails in the treated groups is due to decalcification, as observed in cobaltous sulfate-treated Planorbis exustus and thiourea treated Lymnaea acuminata ${ }^{2,26}$.

These combinations are effective in killing the snails as well as making them sterile since the resulting combinations also kill the eggs in most of the treatments. The use of these natural products in combination with single, binary and tertiary active compounds would have an added advantage in their use against aquatic snails, as they would cause only short-term environmental toxicity, if any.

\section{RESUMO}

Efeitos de combinações unitárias, binárias e terciárias de Jatropha gossypifolia e outros muluscicidas derivados de plantas na reprodução e sobrevivência do caramujo Lymnaea acuminata

O efeito de doses sub-letais ( $40 \%$ e $80 \%$ de LC $_{50} / 24 \mathrm{~h}$ ) de moluscicidas derivados de plantas com combinações unitárias, binárias (1:1) e terciárias (1:1:1) de Rutin, ácido Elágico, Betulin e taraxerol com látex da J. gossypifolia, folhas e extrato em pó de casca de caule e seus componentes ativos foram estudados na reprodução do caramujo de água fresca Lymnaea acuminata. Foi observado que o látex da J. gossypifolia, casca do caule, folhas individualmente e suas combinações com componentes moluscicidas ativos derivados de outras plantas causaram 


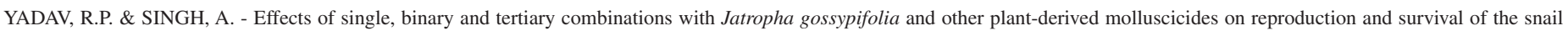
Lymnaea acuminata. Rev. Inst. Med. Trop. Sao Paulo, 56(5): 421-6, 2014.

Table 3

Effects of sub-lethal exposure ( $40 \%$ and $80 \%$ of $24 \mathrm{~h} \mathrm{LC}_{50}$ ) to the powder J. gossypifolia latex+rutin+betulin, J. gossypifolia latex+ellagic acids+betulin and $J$. gossypifolia latex+taraxerol+betulin in combinations (1:1:1) hatchability and survival of young freshwater snail Lymnaea acuminata at different time intervals

\begin{tabular}{|c|c|c|c|c|c|c|}
\hline & Plant part tested & $\begin{array}{c}\text { Concentrations } \\
(\mathrm{mg} / \mathrm{L})\end{array}$ & $\begin{array}{l}\text { \% Hatchability (hatch- } \\
\text { ing period in days) }\end{array}$ & $\begin{array}{c}\text { Survival } 24 \mathrm{~h} \text { after } \\
\text { hatching }(\%)\end{array}$ & $\begin{array}{c}\text { Survival 48h after } \\
\text { hatching }(\%)\end{array}$ & $\begin{array}{c}\text { Survival 72h after } \\
\text { hatching }(\%)\end{array}$ \\
\hline \multirow{7}{*}{$24 \mathrm{~h}$} & \multirow{3}{*}{$\begin{array}{c}\text { J. gossypifolia } \\
\text { latex+Rutin+Betulin }\end{array}$} & Control & $100(11-17)$ & 100 & 100 & 100 \\
\hline & & $40 \%$ of $24 \mathrm{~h} \mathrm{LC}_{50}(2.44)$ & $123.66 \pm 0.463(11-16)$ & $78.16 \pm 0.524$ & $62.50 \pm 0.789$ & $21.34 \pm 0.544$ \\
\hline & & $80 \%$ of $24 \mathrm{~h} \mathrm{LC}_{50}(4.89)$ & $113.66 \pm 0.366(12-17)$ & $78.00 \pm 0.401$ & $61.34 \pm 0.675$ & $16.85 \pm 0.440$ \\
\hline & \multirow{2}{*}{$\begin{array}{l}\text { J. gossypifolia latex+ } \\
\text { Ellagic acids+Betulin }\end{array}$} & $40 \%$ of $24 \mathrm{~h} \mathrm{LC}_{50}(0.68)$ & $135.66 \pm 0.881(11-16)$ & $98.50 \pm 0.245$ & $82.66 \pm 0.732$ & - \\
\hline & & $80 \%$ of $24 \mathrm{~h} \mathrm{LC}_{50}(1.36)$ & $107.66 \pm 0.463(12-17)$ & $88.66 \pm 0.366$ & $52.16 \pm 0.524$ & - \\
\hline & \multirow{2}{*}{$\begin{array}{c}\text { J. gossypifolia } \\
\text { latex+taraxerol+Betulin }\end{array}$} & $40 \%$ of $24 \mathrm{~h} \mathrm{LC}_{50}(1.29)$ & $106.00 \pm 1.236(11-16)$ & $98.00 \pm 0.567$ & $69.00 \pm 0.568$ & - \\
\hline & & $80 \%$ of $24 \mathrm{~h} \mathrm{LC} \mathrm{LC}_{50}(2.59)$ & $83.00 \pm 0.337(12-17)$ & $78.00 \pm 0.401$ & $41.66 \pm 0.366$ & - \\
\hline \multirow{6}{*}{$48 \mathrm{~h}$} & \multirow{2}{*}{$\begin{array}{c}\text { J. gossypifolia } \\
\text { latex+Rutin+Betulin }\end{array}$} & $40 \%$ of $24 \mathrm{~h} \mathrm{LC}_{50}(2.23)$ & $182.51 \pm 0.680(11-16)$ & $146.83 \pm 0.440$ & $97.00 \pm 0.694$ & - \\
\hline & & $80 \%$ of $24 \mathrm{~h} \mathrm{LC}_{50}(4.47)$ & $86.50 \pm 0.618(12-17)$ & $68.50 \pm 0.245$ & $52.50 \pm 0.839$ & - \\
\hline & \multirow{2}{*}{$\begin{array}{l}\text { J. gossypifolia latex+ } \\
\text { Ellagic acids+Betulin }\end{array}$} & $40 \%$ of $24 \mathrm{~h} \mathrm{LC}_{50}(0.58)$ & $201.52 \pm 0.470(11-16)$ & $182.83 \pm 0.772$ & $108.51 \pm 0.838$ & - \\
\hline & & $80 \%$ of $24 \mathrm{~h} \mathrm{LC}_{50}(1.16)$ & $197.16 \pm 0.822(12-17)$ & $173.16 \pm 0.772$ & $108.32 \pm 0.612$ & - \\
\hline & \multirow{2}{*}{$\begin{array}{c}\text { J. gossypifolia } \\
\text { latex+taraxerol+Betulin }\end{array}$} & $40 \%$ of $24 \mathrm{~h} \mathrm{LC}_{50}(1.19)$ & $196.35 \pm 0.785(11-16)$ & $192.00 \pm 0.401$ & $124.34 \pm 0.543$ & - \\
\hline & & $80 \%$ of $24 \mathrm{hLC}_{50}(2.39)$ & $123.50 \pm 0.838(12-17)$ & $101.67 \pm 0.926$ & $91.50 \pm 0.470$ & - \\
\hline \multirow{6}{*}{$72 \mathrm{~h}$} & \multirow{2}{*}{$\begin{array}{c}\text { J. gossypifolia } \\
\text { latex+Rutin+Betulin }\end{array}$} & $40 \%$ of $24 \mathrm{~h} \mathrm{LC}_{50}(2.11)$ & $122.00 \pm 0.401(11-16)$ & $118.16 \pm 0.596$ & $109.16 \pm 0.524$ & - \\
\hline & & $80 \%$ of $24 \mathrm{~h} \mathrm{LC}_{50}(4.22)$ & $106.00 \pm 0.694(12-17)$ & $96.00 \pm 0.491$ & $87.17 \pm 0.661$ & - \\
\hline & \multirow{2}{*}{$\begin{array}{l}J . \text { gossypifolia latex+ } \\
\text { Ellagic acids+Betulin }\end{array}$} & $40 \%$ of $24 \mathrm{~h} \mathrm{LC}_{50}(0.50)$ & $210.34 \pm 0.881(11-16)$ & $172.66 \pm 0.366$ & $115.00 \pm 0.401$ & - \\
\hline & & $80 \%$ of $24 \mathrm{~h} \mathrm{LC}_{50}(1.00)$ & $196.66 \pm 0.834(12-17)$ & $166.16 \pm 0.524$ & $104.16 \pm 0.822$ & - \\
\hline & \multirow{2}{*}{$\begin{array}{c}\text { J. gossypifolia } \\
\text { latex+taraxerol+Betulin }\end{array}$} & $40 \%$ of $24 \mathrm{~h} \mathrm{LC}_{50}(1.07)$ & $241.83 \pm 0.598(11-16)$ & $216.50 \pm 0.838$ & $196.33 \pm 0.463$ & - \\
\hline & & $80 \%$ of $24 \mathrm{hLC}_{50}(2.15)$ & $207.17 \pm 0.524(12-17)$ & $192.33 \pm 0.675$ & $189.30 \pm 0.543$ & - \\
\hline \multirow{6}{*}{$96 \mathrm{~h}$} & \multirow{2}{*}{$\begin{array}{c}\text { J. gossypifolia } \\
\text { latex+Rutin+Betulin }\end{array}$} & $40 \%$ of $24 \mathrm{~h} \mathrm{LC}_{50}(2.00)$ & $114.16 \pm 0.524(11-16)$ & $101.66 \pm 0.926$ & $83.83 \pm 0.870$ & - \\
\hline & & $80 \%$ of $24 \mathrm{~h} \mathrm{LC}_{50}(4.00)$ & $103.66 \pm 0.732(12-17)$ & $95.50 \pm 0.736$ & $83.67 \pm 0.881$ & - \\
\hline & \multirow{2}{*}{$\begin{array}{l}\text { J. gossypifolia latex+ } \\
\text { Ellagic acids+Betulin }\end{array}$} & $40 \%$ of $24 \mathrm{~h} \mathrm{LC}_{50}(0.41)$ & $196.18 \pm 0.524(11-16)$ & $168.83 \pm 0.772$ & $112.16 \pm 0.524$ & - \\
\hline & & $80 \%$ of $24 \mathrm{~h} \mathrm{LC}_{50}(0.82)$ & $163.66 \pm 0.881(12-17)$ & $107.00 \pm 0.634$ & $96.16 \pm 0.660$ & - \\
\hline & \multirow{2}{*}{$\begin{array}{c}\text { J. gossypifolia } \\
\text { latex+taraxerol+Betulin }\end{array}$} & $40 \%$ of $24 \mathrm{~h} \mathrm{LC}_{50}(0.96)$ & $167.16 \pm 0.660(11-16)$ & $119.33 \pm 0.885$ & $95.50 \pm 0.051$ & - \\
\hline & & $80 \%$ of $24 \mathrm{~h} \mathrm{LC}_{50}(1.92)$ & $196.17 \pm 0.524(12-17)$ & $115.33 \pm 0.968$ & $82.16 \pm 0.052$ & - \\
\hline
\end{tabular}

Details as given in Table 1.

redução significante na fecundidade, incubação e sobrevivência dos caramujos jovens. Acredita-se que a exposição sub-letal destes moluscicidas sobre a reprodução dos caramujos é processo complexo envolvendo mais de um fator na redução da capacidade reprodutiva.

\section{REFERENCES}

1. Agarwal RA, Singh DK. Harmful gastropods and their control. Acta Hydrochim Hydrobiol. 1988;16:113-38.

2. Bhide M. Effect of thiourea on the development of Lymnaea stagenalis. Symp Man Bio Dev Environ. 1986;46:42.

3. Bhide M. Effect of nuvan, methyl parathion and thimet on the mortality, behaviour and reproduction performance of freshwater mollusk, Lymnaea stagnalis. J Environ Biol. 1998;19:325-32.
4. Bell E, Reeder R. The effect of fertilization on protein synthesis in the egg of the surf clam Spisula solidissima. Biochem Biophys Acta. 1976;142:500-11.

5. Brahmachary RL, Palchoudhury SR. Further investigations on transcription and translation in Lymnaea embryos. Can J Biochem. 1971;49:926-32.

6. Collier JR. Nucleic acid synthesis in the normal and lobeless embryo of Ilyanassa obsoleta. Exp Cell Res. 1975;95:254-62.

7. Collier JR. Nucleic acid chemistry of the IIyanassa embryo. Am Zool. 1976;16:483-500

8. Firtel RA, Monroy A. Polysomes and RNA synthesis during early development of the surf clam Spisula solidissima. Dev Biol. 1970;21:87-104.

9. Godan D. Pest slugs and snails: biology and control. Berlin: Springer Verlag; 1983. 
YADAV, R.P. \& SINGH, A. - Effects of single, binary and tertiary combinations with Jatropha gossypifolia and other plant-derived molluscicides on reproduction and survival of the snail Lymnaea acuminata. Rev. Inst. Med. Trop. Sao Paulo, 56(5): 421-6, 2014.

10. Goets FW, Theofan G. In vitro stimulation of germinal vesicle breakdown and ovulation of yellow perch (Perca flavescens) oocytes. Effects of 17-hydroxyl-20 $\beta$-dihydroprogesterone and prostaglandins. Gen Comp Endocrinol. 1979;37:273-85.

11. Gupta DR, Garg SK. A chemical examination of Euphorbia hirta Linn. Bull Chem Soc Jpn. 1966;39:2532-4.

12. Hafs HD, Louis TM, Stellflug JN. Increased sperm numbers in the deferent duct after prostaglandin $\mathrm{F}_{2} \alpha$ in rabbits. Proc Soc Exp Biol Med. 1974;145:1120-4.

13. Hyman LH. The invertebrate. In: Mollusca I. New York: Mc Graw Hill; 1970. v. VI.

14. Katz N. Possibilidade de controle da esquistossomose. J Bras Med. 1986; 50:85-8.

15. Kidder G. The ribosomal RNA cistrons in clam gametes. Dev Biol. 1976a;49:132-42.

16. Kidder G. RNA synthesis and the ribosomal cistrons in early molluscan development. Am Zool. 1976b;16:501-20.

17. Marston A, Hostettmann K. Plant molluscicides. Phytochemistry. 1985;24:639-52.

18. McCullough FS. Snail control in relation to a strategy for reduction of morbidity due to schistosomiasis. Trop Med Parasitol. 1986;37:181-4.

19. Morrill JB, Rubin RW, Grandi M. Protein synthesis and differentiation during pulmonate development. Am Zool. 1976;16:547-61.

20. Moore NW, Eppleston J. The control of oestrus, ovulation and fertility in relation to artificial insemination in the Angora goat. Aust J Agric Res. 1979;30:965-72.

21. Nomura T, Ogata H, Lucas A. Mise en evidence de prostaglandines chez des mollusques bivalves. Rev Int Oceanogr Med. 1979;53-54:87-94.

22. Presing M. Influence of an insecticide, K-Othrine, on the reproduction and mortality of the pond snail (Lymnaea stagnalis L.). Arch Environ Contam Toxicol. 1993;25:387-93.

23. Rastogi RP, Mehrotra BN. Compendium Indian medicinal plants. New Delhi: PID/ICMR; 1990a. v. 1, p. 131.

24. Rastogi RP, Mehrotra BN. Compendium Indian medicinal plants. New Delhi: PID/ICMR; 1990b. v. 1, p. 183

25. Schall VT, Vasconcellos MC, Souza CP, Baptista DF. The molluscicidal activity of crown of Christ (Euphorbia splendens var hislopii) latex on snails acting as intermediate hosts of Schistosoma mansoni and Schstosoma haematobium. Am J Trop Med Hyg. 1998;58:7-10.

26. Sherbet GV, Lakshmi MS. Inhibition of development of Planorbis exustus by cobaltous sulphate and chloramphenicol. Naturwissenchaften. 1964;51:119.

27. Singh A, Singh DK, Mishra TN, Agarwal RA. Molluscicides of plant origin. Biol Agric Hortic. 1996;13:205-52.
28. Singh O, Agarwal RA. Toxicity of certain pesticides to two economic species of snails in northern India. J Econ Entomol. 1981;74:568-71.

29. Sokal RR, Rohlf FJ. Introduction of biostatistics. San Franscisco: Freeman WH \& Co.; 1973.

30. Stryer L. Hormone action: prostaglandins are modulators of hormone action. In: Biochemistry. San Francisco: Freeman WH \& Co.; 1975. p. 821-2.

31. Tapaswi PK. RNA synthesis during "oogenesis to the onset of fertilization" in Lymnaea (Mollusc). Z Naturforschung B. 1972;27:581-2.

32. Tapaswi PK. Further investigation on transcription during oogenesis and immediately after activation by sperm in Lymnaea (Mollusca) eggs. Acta Embryol Exp (Palermo). 1974;2:191-7.

33. Thomas JD. Schistosomiasis and the control of molluscan hosts of human schistosomes with particular reference to possible self-regulatory mechanisms. Adv Parasitol. 1973;11:307-94

34. Van den Biggelaar JAM. RNA synthesis during cleavage of the Lymnaea egg. Exp Cell Res. 1971a;67:207-10.

35. Van den Biggelaar JAM. Timming of the phases of the cell cycle with tritiated thymidine and feulgen cytophotometry during the period of synchronous division in Lymnaea. J Embryol Exp Morphol. 1971b;26:353-66.

36. Van den Biggelaar JAM. Timming of the phases of the cell cycle during the period of asynchronous division up to the 49-cell stage in Lymnaea. J Embryol Exp Morphol. 1971c;26:367-91.

37. World Health Organization. Snail control and prevention of bilharziasis. Geneva: WHO 1965. (Monog. Ser. No. 5).

38. Yadav RP, Singh A. Environmentally safe molluscicides from two common euphorbiales. Iberus. 2001; 19:65-73

39. Yadav RP, Singh A. Toxic effects of latex of Croton tiglium on Lymnaea acuminata and Channa punctatus. Iberus. 2002;20:33-45.

40. Yadav RP, Tiwari S, Singh A. Toxic effect of taraxerol extracted Codiaeum variegatum stem bark on target vector snail Lymnaea acuminata and non-target fish. Iberus. 2005;23:1-13.

41. Yadav RP, Singh A. Toxic effects of Jatropha gossypifolia and its binary and tertiary combinations with other plant molluscicides in natural ponds. Iberus. 2006;24:47-54.

Received: 31 July 2013

Accepted: 3 February 2014 